\title{
Surface treatment of red mud and its influence on the properties of particulate-filled polyester composites
}

\author{
B SINGH and M GUPTA \\ Central Building Research Institute, Roorkee 247667, India \\ MS received 25 October 1994; revised 11 July 1995
}

\begin{abstract}
The red mud surface was treated with organosilane, organotitanate and organozirconate coupling agents respectively. The change in the surface was determined by IR spectroscopy and SEM. The effect of coupling agents concentration on the tensile and flexural strength of red mud-filled polyester resin has been studied. The efficacy of these coupling agents was discussed in relation to dispersion of red mud in unsaturated polyester resin and also by measuring performance of finished castings under both dry and wet conditions. It was found that organotitanate treated red mud-filled polyester composite gives better physico-mechanical properties than the control and other coupling agents treated red mud. Fractography of failed samples was also discussed in terms of their mechanical properties.
\end{abstract}

Keywords. Red mud; unsaturated polyester resin; red mud-filled polyester composites; coupling agents.

\section{Introduction}

The inclusion of particulate fillers in polymeric materials is an established practice in the polymer industry. However, their inclusion results in an increase in viscosity and degradation of some of its mechanical properties of the polymers (Katz and Milewski 1978). The retention of the desired strength properties of filled polymers requires an adequate bonding between the polymer and the filler. In recent years, many publications have appeared in the literature on modification of particulate fillers with coupling agents (Kenyon 1968; Kenyon and Duffy 1970; Broutman and Sahu 1971; Han et al 1978; Monte and Sugarman 1981; Ishida and Koenig 1978; Plueddemann 1982; Favis et al 1983; Rodriguez and Newaz 1988; Moloney et al 1984; Spandoukis and Young 1984; Molphy et al 1994). These modifications, as well, improve the filler-matrix interaction and consequently the particulate dispersion in the matrix.

In the present work, red mud, an industrial waste of aluminium industry was used as filler in unsaturated polyester resin due to its availability in huge quantity of $\sim 2$ million tonnes per annum (Panda 1992) at nominal cost. Earlier, studies on utilization of red mud as filler in PVC resin (UIRL), rubber (Ketomo 1952; Aramine et al 1961), paints and pigments (Vogel 1965; Ramanujam and Saluja 1965; Guruviah and Rajagopalan 1966) and unsaturated polyester resin (Chand 1991; Singh et al 1995) have been reported. In such applications, it is advantageous to beneficiate the red mud into components and various size fractions which have a variety of potential. Ketomo (1952) and Aramine et al (1961) have prepared a filler from acid digestion of red mud for rubber reinforcement resulting in improved mechanical properties. The inherent drawbacks associated in the processing, poor strength properties and performance of finished products in end-use applications have further necessitated attention. The failure of RMP sheets under Indian climatic conditions is well known. The consequences of using 
red mud has not been so widely studied and the significance and relative importance of particle characteristics and their surface treatment are not so well known. Since red mud as a filler is a combination of many such fillers, polymer-filler interaction will be a complicated system. Keeping in view, surface modification of red mud is essential for obtaining the desired properties of composites. In this paper, we report the effect of surface treated red mud on the properties of particulate-filled polyester composites. The failure of these composites through matrix cracking, debonding at the interface and poor dispersion of particles in the matrix is also discussed in terms of its mechanical test. This is the first report on this system to the best of my knowledge.

\section{Experimental}

\subsection{Materials}

Red mud (pH 9.6, density $2.89 \mathrm{~g} / \mathrm{cm}^{3}$; surface area $0.216 \mathrm{~m}^{2} \mathrm{~g}^{-1}$; average particle size $27 \cdot 2 \mu \mathrm{m}$ ) was obtained from the Indian Aluminium Company (Indalco), Alwaye and its chemical composition is described in our earlier publication (Singh et al 1995). Unsaturated polyester resin (HSR 8131) along with its ancillaries was procured from

Table 1. Details of treatment conditions for red mud.

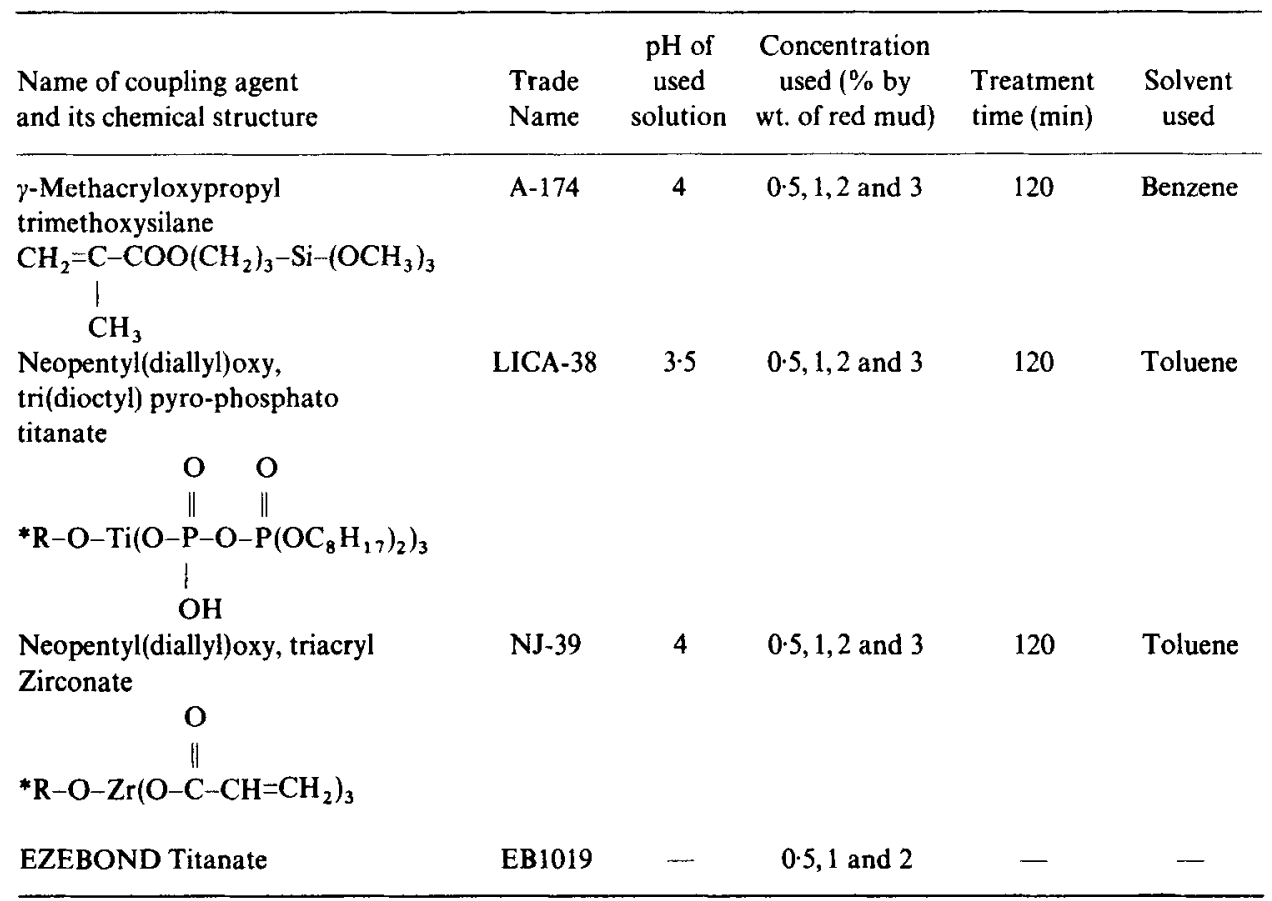

${ }^{*} \mathrm{R}=\mathrm{CH}_{2}=\mathrm{CH}-\mathrm{CH}_{2} \mathrm{O}-\mathrm{CH}_{2}$

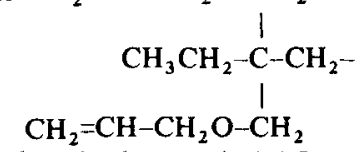

Red mud-solvent ratio $1: 1 \cdot 5$ 
M/s Bakelite Hylam Ltd., Hyderabad. Coupling agents such as gamma-methacryloxy propyl trimethoxy-silane, A-174 (Union Carbide, USA), neopentyl (diallyl)oxy, tri (dioctyl) pyro-phosphato titanate, LICA-38 (Kenrich Petrochemicals, USA), neopentyl (diallyl) oxy, triacryl zirconate, NJ-39 (Kenrich Petrochemicals, USA) and EZEBOND titanate, EB 1019 (Industrial Products Manufacturing Company, Pune) were used without further purification.

\subsection{Coating of red mud and its evaluation}

Red mud was first calcined at $200^{\circ} \mathrm{C}$ for $24 \mathrm{~h}$ and washed with distilled water. The sample was dried at $100^{\circ} \mathrm{C}$ for $24 \mathrm{~h}$, sieved and stored in a desiccator before use. Treatment of red mud was carried out from a $1 \%$ (by wt. of red mud) solution of coupling agent in respective solvent. The slurry was agitated for $2 \mathrm{~h}$ and filtered on a buchner filter. The sample was then washed with respective solvent to remove

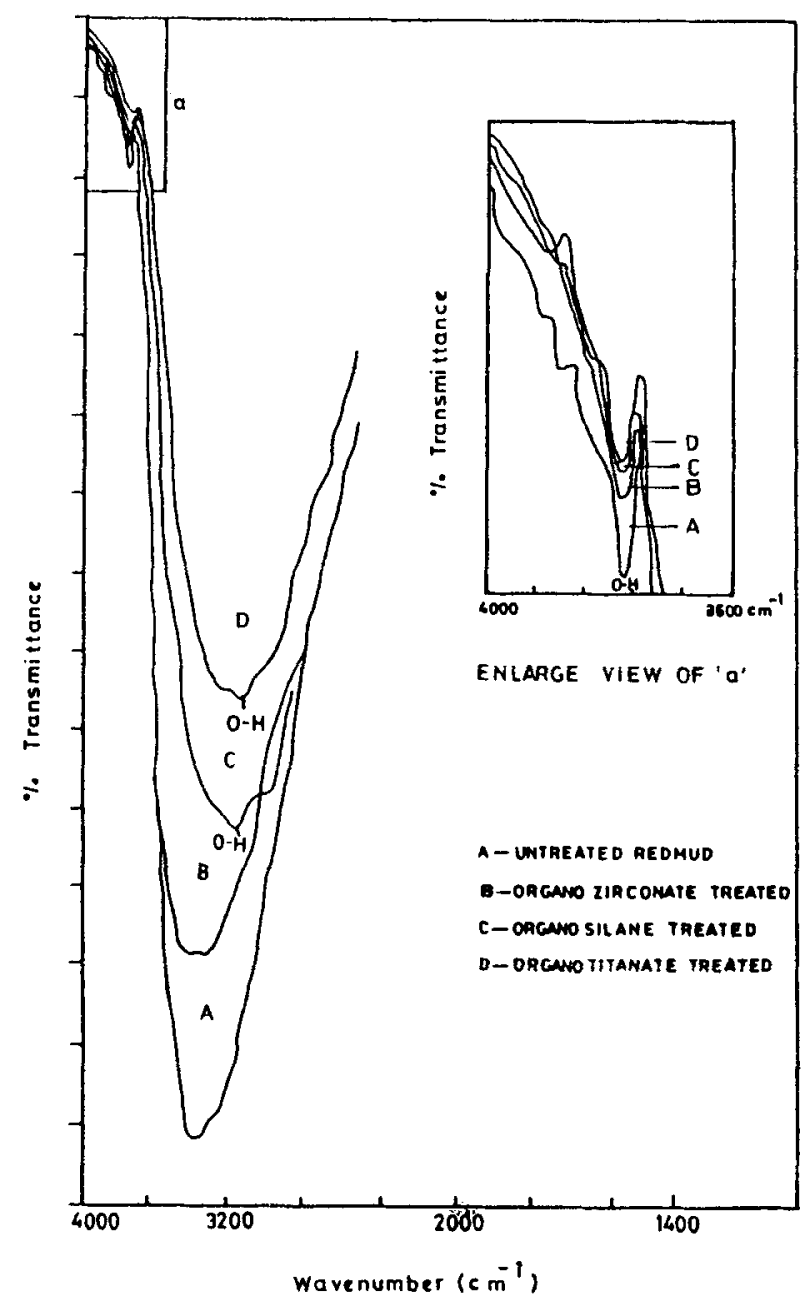

Figure 1. IR spectra of untreated and treated red mud showing hydroxyl groups. (a: Enlarged view of spectra at $3780 \mathrm{~cm}^{-1}$ showing displaced hydroxyl groups). 

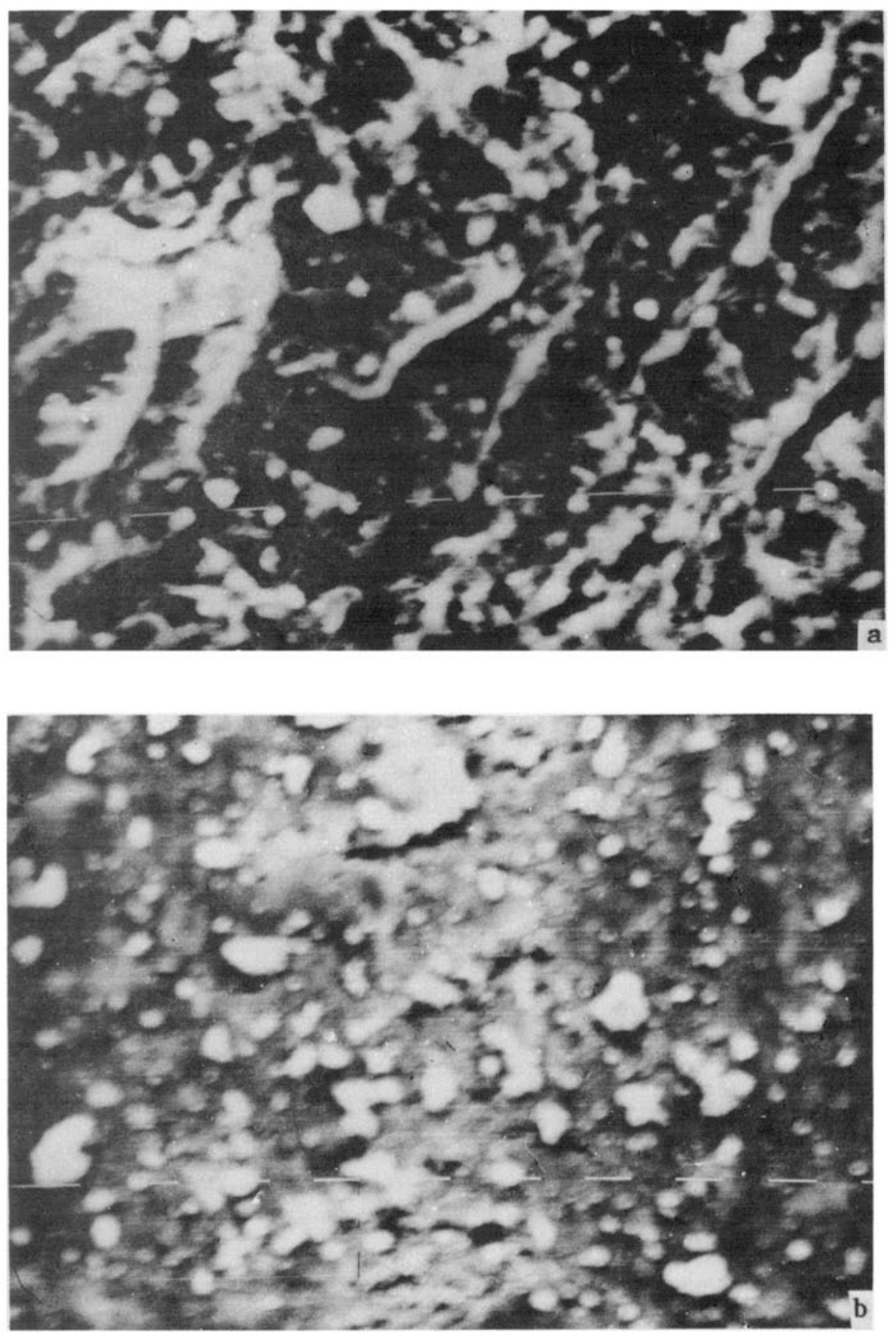

Figure 2. a-b. 

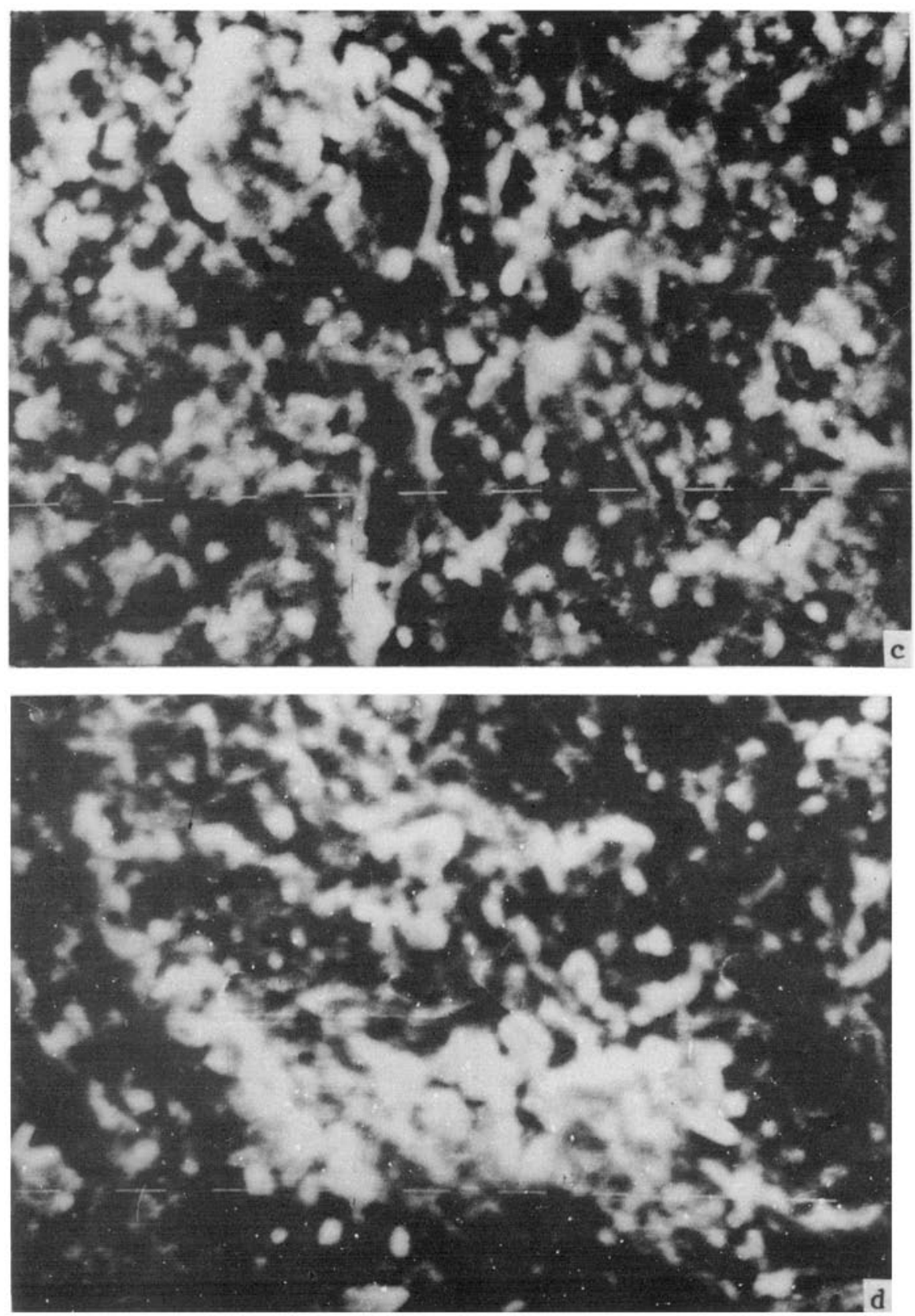

Figure 2. a. SEM of untreated red mud dispersed in resin matrix ( $\times 768)$, b. SEM of silane treated red mud dispersed in resin matrix $(\times 832)$, c. SEM of titanate treated red mud dispersed in resin matrix $(\times 896)$ and $d$. SEM of zirconate treated red mud dispersed in resin matrix $(\times 768)$. 
unreacted coupling agent and dried at $80^{\circ} \mathrm{C}$ for $4 \mathrm{~h}$ to complete the condensation process. The conditions of treatments are given in table 1 . It may be noted that EZEBOND titanate coupling agent was added directly to the resin and mixed thoroughly. This was followed by gradual addition of red mud.

Dispersion of both untreated and treated red mud was evaluated by measuring Daniel flow point (Daniel 1950). In this flow test, $6 \mathrm{~g}$ of both untreated and treated red mud was titrated with $25 \%$ solution of unsaturated polyester resin in styrene. The mixture was thoroughly stirred. End point was noted when the mixture became fluid enough to flow from spatula. Viscosity of both untreated and treated red mud-filled polyester resin was measured by viscometer (Brookfield, DT II, USA) at 20 RPM. The presence of coupling agent on the surface of red mud (figures 1-3) was confirmed by infrared spectrophotometer (Perkin-Elmer 883) and scanning electron microscope (Phillips, 501, Holland). The average particle size of red mud and its distribution determined by EASY particle sizer (Malvern Instruments) is given in table 4.

\subsection{Preparation of particulate composite samples and their evaluation}

The composites were prepared by mixing different percentages (by volume) of both untreated and treated red mud with unsaturated polyester resin containing $1.5 \%$ methyl ethyl ketone peroxide (catalyst) and 1.5\% cobalt naphthenate (accelerator). The mixture was slowly rotated to prevent sedimentation until polymerization rendered it viscous. It was then poured into metal mould of $4 \mathrm{~mm}$ thickness, allowed to polymerize at room temperature for $24 \mathrm{~h}$ and then post cured at $80^{\circ} \mathrm{C}$ for $4 \mathrm{~h}$. Polyvinyl alcohol was used as mould releasing agent. Test specimens were cut from casted sheets for evaluation work. In order to study the efficacy of coupling agents, the composites containing $24 \mathrm{vol} \%$ was used owing to sufficient viscosity of mixture to permit the elimination of entrapped air.

The water absorption of both untreated and treated red mud-filled polyester composites was examined as per ASTM D-570-81. Tensile properties of composites were determined in accordance with ASTM D-638-76 at a cross head speed of $5 \mathrm{~mm} / \mathrm{min}$ (UTM ZWICK-1474, Germany). Flexural strength of the specimens was measured at a cross head speed of $5 \mathrm{~mm} / \mathrm{min}$ and span-to-depth ratio of $16: 1$ in accordance with ASTM D-790-91 (UTM ZWICK-1474, Germany). The data given are the mean values of three results for water absorption and five results for tensile and flexural tests. The standard deviations on the tensile and flexural strength data are about $\pm 5 \%$. The fractured surfaces of red mud-filled polyester composites were examined with the help of SEM (Phillips, 501, Holland).

\section{Results and discussion}

Figure 4 shows the effect of various coupling agents on the tensile and flexural strength of particulate-filled polyester composites. It can be seen that in each case a distinct maxima was observed in the curves at a certain concentration (critical concentration) showing sufficient availability of coupling agent to bond the surface functional groups of red mud and resin matrix. Organotitanate and organosilane improved the tensile strength of composites at a level of $1 \%$ (by wt. of red mud) while organozirconate and EZEBOND titanate performed well at a level of $0.5 \%$ (by wt. of 

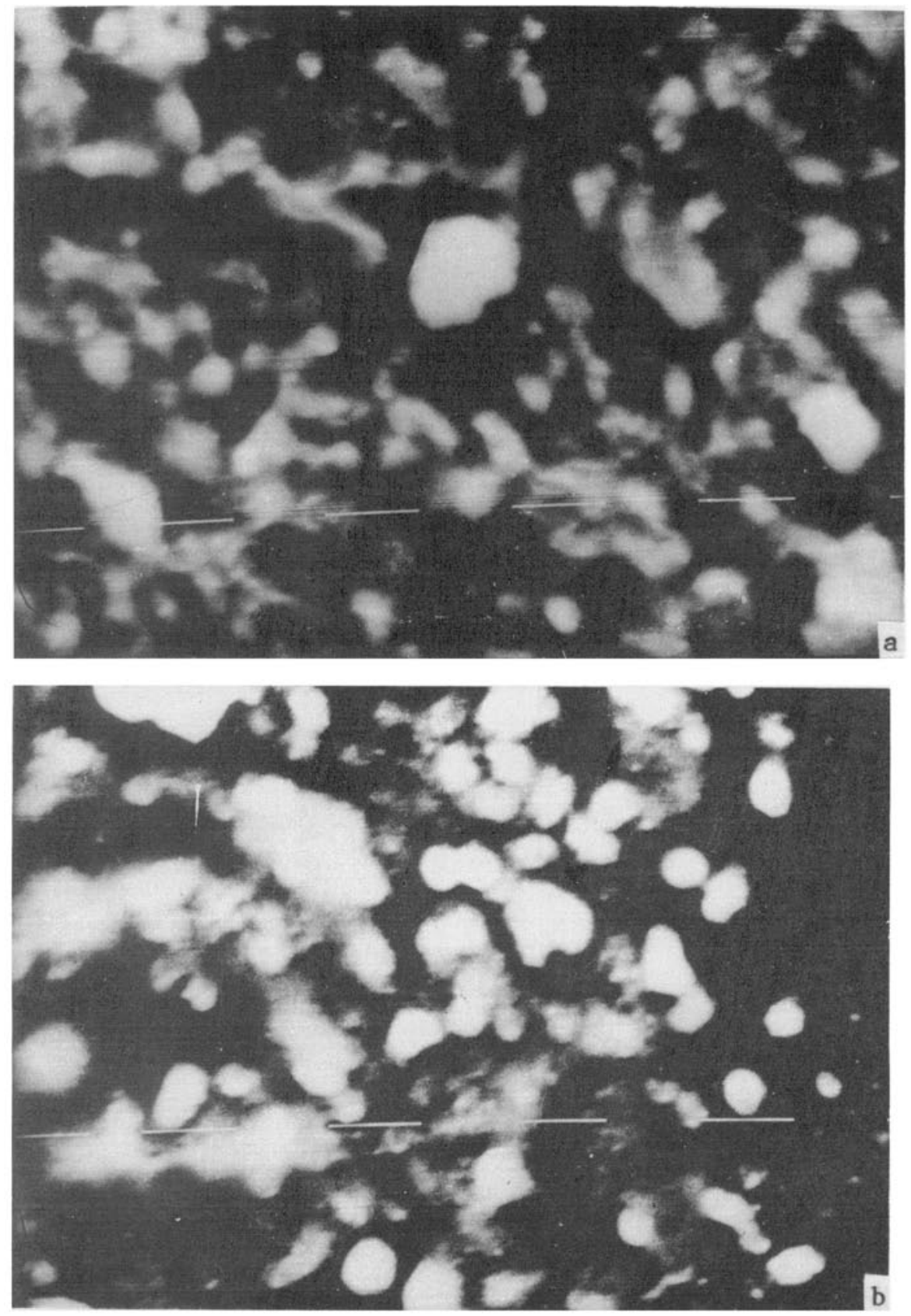

Figure 3. $a-b$. 

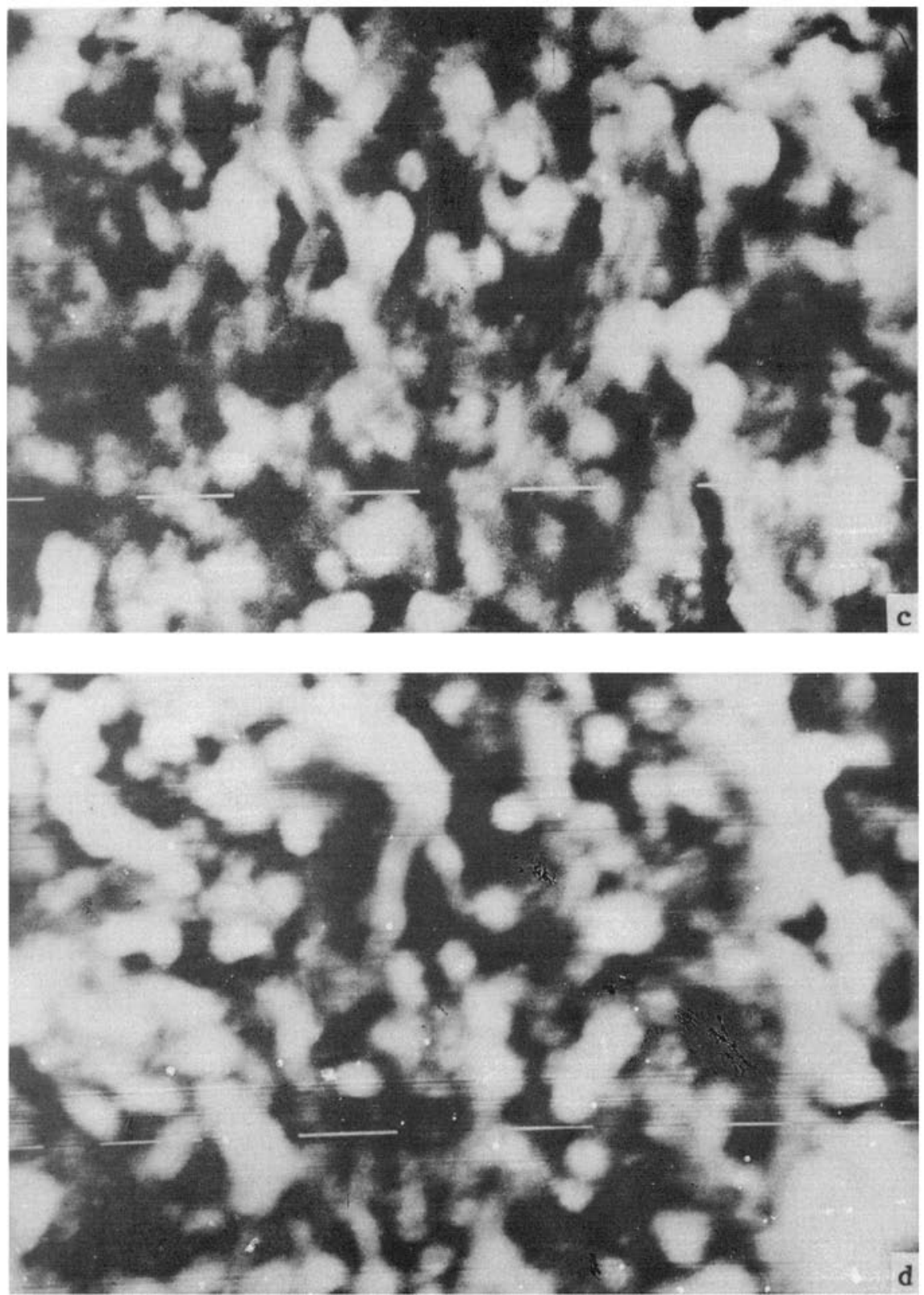

Figure 3. SEM at higher magnification showing a. untreated red mud dispersed in USP resin matrix $(\times 1625)$, b. silane treated red mud dispersed in USP resin $(\times 1625)$, c. titanate treated

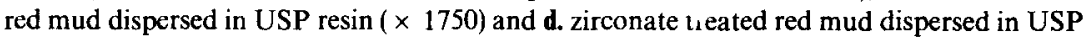
resin $(\times 1500)$. 
Table 2. Surface characterization of untreated and treated red mud (coupling agent $=1 \%$ by wt. of red mud).

\begin{tabular}{lccccc}
\hline & $\begin{array}{c}\text { Daniel } \\
\text { flow } \\
\text { point } \\
\text { (ml) }\end{array}$ & $\begin{array}{c}\text { Surface } \\
\text { area } \\
\text { (Sqm/g) }\end{array}$ & $\begin{array}{c}\text { Viscosity } \\
\text { (cps) }\end{array}$ & $\begin{array}{c}\text { Dispersion of } \\
\text { particles in resin } \\
\text { (SEM observation) }\end{array}$ & $\begin{array}{c}\text { Relative \% change } \\
\text { in transmittance } \\
\text { of -OH group } \\
\text { at } 3780 \mathrm{~cm}^{-1}\end{array}$ \\
\hline Surface treatment & 3.1 & 0.216 & 1600 & $\begin{array}{l}\text { Dispersed particles } \\
\text { alongwith agglomerates }\end{array}$ & - \\
\hline Untreated red mud & 2.8 & 0.440 & 1500 & Uniform and good & 33.33 \\
$\begin{array}{l}\text { Pyro-phosphato titanate } \\
\text { treated red mud }\end{array}$ & 2.8 & 0.295 & 1480 & Satisfactory & 50 \\
$\begin{array}{l}\text { Methacrylate silane } \\
\text { treated red mud }\end{array}$ & 2.9 & 0.260 & 1600 & $\begin{array}{l}\text { Localized dense } \\
\text { particles }\end{array}$ & 66.66 \\
$\begin{array}{l}\text { Acryl zirconate } \\
\text { treated red mud }\end{array}$ & & & & Satisfactory & - \\
$\begin{array}{l}\text { EZEBOND titanate } \\
\text { (directly added } \\
\text { to the resin) }\end{array}$ & - & - & - & & \\
\hline
\end{tabular}

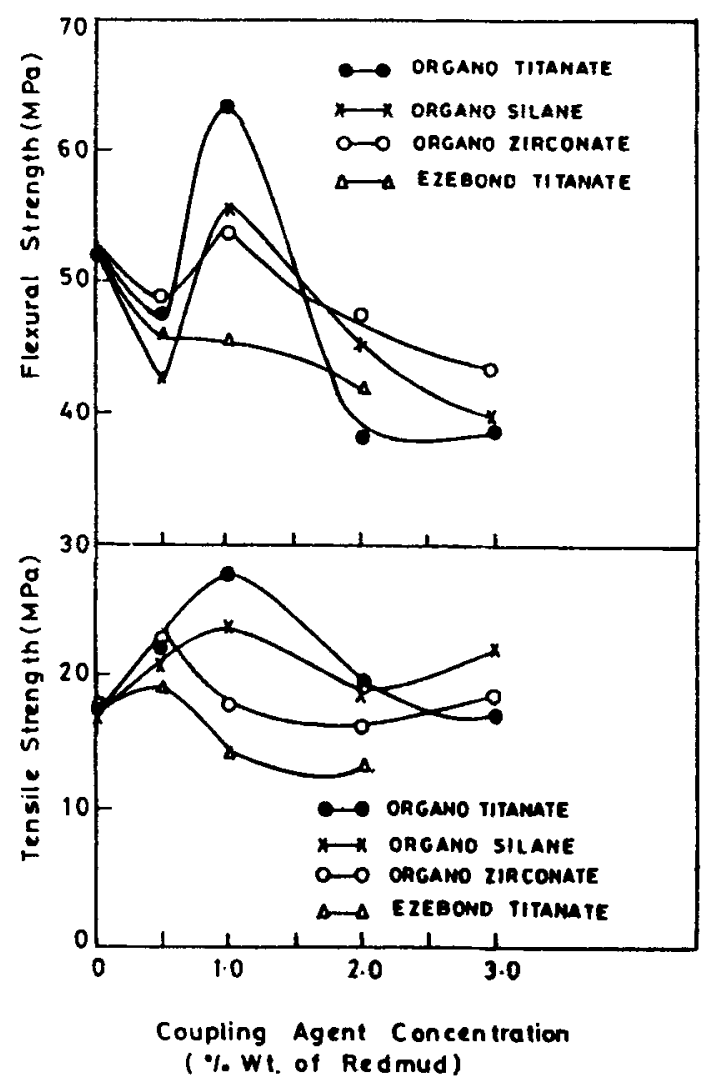

Figure 4. Effect of different coupling agents on tensile and flexural strength of red mud-filled polyester composites (red mud loading $=24 \mathrm{vol} . \%$ ). 
Table 3. Physico-mechanical properties of untreated and treated red mud-filled polyester composites (Red mud loading $=24 \mathrm{vol} \%$ ) coupling agent $=1 \%$ by wt. of red mud).

\begin{tabular}{|c|c|c|c|c|c|c|c|}
\hline \multirow[b]{3}{*}{ Composite } & \multirow{3}{*}{$\begin{array}{l}\text { Density } \\
\left(\mathrm{g} / \mathrm{cm}^{3}\right)\end{array}$} & \multirow{2}{*}{\multicolumn{2}{|c|}{$\begin{array}{c}\text { Water absorption } \\
(24 \mathrm{~h}, \%)\end{array}$}} & \multirow{3}{*}{$\begin{array}{c}\text { Tensile } \\
\text { strength } \\
\text { (MPa) }\end{array}$} & \multirow{3}{*}{$\begin{array}{c}\text { Elongation } \\
(\%)\end{array}$} & \multicolumn{2}{|c|}{ Flexural strength (MPa) } \\
\hline & & & & & & & $\%$ retention after \\
\hline & & RT & $60^{\circ} \mathrm{C}$ & & & Dry & $24 \mathrm{~h}$ boiling \\
\hline Untreated red mud & 1.463 & 0.135 & 0.513 & $17 \cdot 35$ & 2.52 & $52 \cdot 10$ & $60 \cdot 46$ \\
\hline $\begin{array}{l}\text { Organotitanate } \\
\text { treated red mud }\end{array}$ & 1.505 & 0.016 & 0.269 & $27 \cdot 79$ & $2 \cdot 38$ & 63.52 & $68 \cdot 36$ \\
\hline $\begin{array}{l}\text { Organosilane } \\
\text { treated red mud }\end{array}$ & 1.462 & 0.069 & $0 \cdot 165$ & $23 \cdot 72$ & $2 \cdot 38$ & $56 \cdot 12$ & $72 \cdot 17$ \\
\hline $\begin{array}{l}\text { Organozirconate } \\
\text { treated red mud }\end{array}$ & 1.473 & 0.101 & 0.329 & $17 \cdot 68$ & $2 \cdot 27$ & 53.98 & $69 \cdot 14$ \\
\hline $\begin{array}{l}\text { EZEBOND } \\
\text { titanate treated } \\
\text { red mud }\end{array}$ & 1.465 & 0.101 & $0 \cdot 313$ & $13 \cdot 84$ & $2 \cdot 50$ & $45 \cdot 56$ & $67 \cdot 16$ \\
\hline
\end{tabular}

red mud). In flexure, only improvement in strength was observed for organotitanate treated red mud-filled composites at critical concentration over the control. Beginning from this concentration, the strength decreases with increasing coupling agents concentration. Above observations are identical with the work of Sung et al (1982), Wong (1972), Eckstein and Berger (1983) and Plueddemann (1983) for other particulate composites. The higher content of physisorbed coupling agent on the surface of red mud and subsequent formation of matrix interface consisting of physisorbed coupling agent (desorbed during polymerization from the surface of red mud) and matrix near the filler surface (Ishida and Koenig 1980) have been considered for the explanation of poor strength of composites above the critical concentration.

Tables 2 and 3 compare the properties of various coupling agents treated red mud and red mud-filled polyester composites. It is evident that the composites prepared from organotitanate treated red mud showed better physico-mechanical properties than the control and the composites prepared from organosilane, organozirconate and EZEBOND titanate treated red mud (table 3). This behaviour can be explained in terms of dispersion of red mud in unsaturated polyester resin as a consequence of molecular wetting and the bonding between red mud and unsaturated polyester resin as a result of specific chemical interaction with each component at the interface. The additional strength provided by $\mathrm{Ti}-\mathrm{O}-\mathrm{M}$ bond (due to presence of high $\mathrm{TiO}_{2}$ content in red mud) over $\mathrm{Si}-\mathrm{O}-\mathrm{M}$ and $\mathrm{Zr}-\mathrm{O}-\mathrm{M}$ bonds could also be one possible reason for better performance of organotitanate treated red mud-filled polyester composites.

Dispersion of red mud in unsaturated polyester resin is given in table 2 . As could be expected, the lower value of Daniel flow point of treated red mud gives better dispersion resulting from more uniform coverage of coupling agent on the surface of red mud particles. However, it is difficult to establish the efficacy of various coupling agents on the basis of Daniel flow point data, since most of them have similar value. Therefore, SEM was used to examine the dispersion of red mud particles in unsaturated polyester resin (table 2, figures 2 and 3). It can also be seen from fractured photographs (figures 9-13) that organosilane and organotitanate coupling agents seem to display satisfactory and more uniform dispersion due to their better displacement 


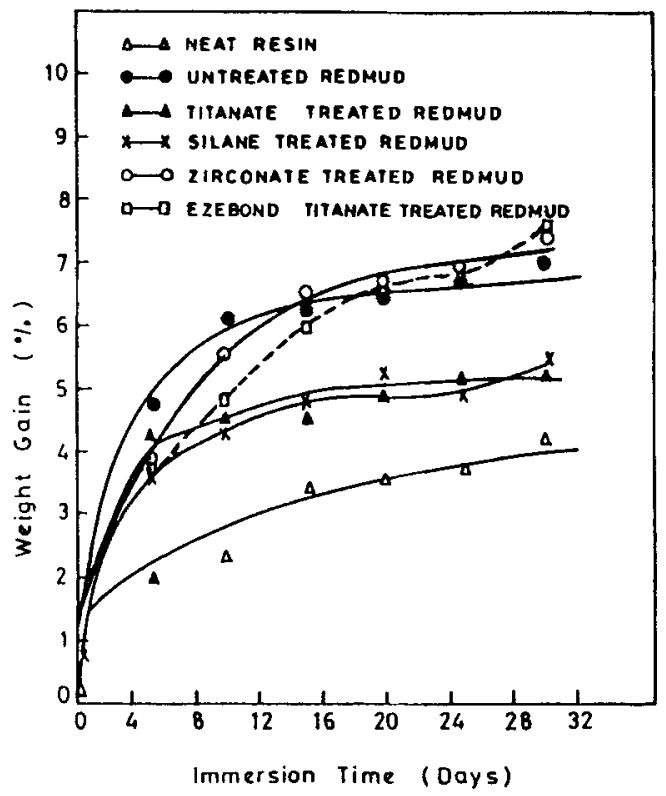

Figure 5. Water absorption of neat and red mud-filled polyester resin as a function of immersion time at room temperature (red mud loading $=24 \mathrm{vol} \%$, coupling agent $=1 \%$ by wt. of red mud).

Table 4. Effect of particle size on the tensile and flexural strength of red mud-filled polyester composites (red mud $24 \mathrm{vol} \%$ ).

\begin{tabular}{rcccc}
\hline \multicolumn{3}{c}{ Particle size distribution } & & \\
\cline { 1 - 2 } $\begin{array}{c}\text { D10 } \\
(\mu \mathrm{m})\end{array}$ & $\begin{array}{c}\text { D50* } \\
(\mu \mathrm{m})\end{array}$ & $\begin{array}{c}\text { D90 } \\
(\mu \mathrm{m})\end{array}$ & $\begin{array}{c}\text { Tensile strength } \\
(\mathrm{MPa})\end{array}$ & $\begin{array}{c}\text { Flexural strength } \\
(\mathrm{MPa})\end{array}$ \\
\hline $11 \cdot 7$ & 27.2 & 33.3 & 17.35 & $52 \cdot 10$ \\
6.2 & 14.3 & 29.0 & 21.00 & 58.00 \\
4.5 & 11.2 & 28.0 & 24.35 & 64.12 \\
3.3 & 8.1 & 21.7 & 27.10 & 71.56 \\
\hline
\end{tabular}

*Average particle size

tendency of hydrophillic polar hydroxyl groups from the red mud surface with a hydrophobic alkoxy-hydrolyzable group of central atom containing methacrylate and pyro-phosphato organofunctionality as compared to organozirconate and EZEBOND titanate coupling agents. These groups could reduce the amount of water which glues the red mud particles together and reduces the grouping effect. Displaced hydroxyl group at $3780 \mathrm{~cm}^{-1}$ could be seen in the spectra of treated red mud (figure 1). The additional $\mathrm{O}-\mathrm{H}$ stretching band starts to appear at $3290 \mathrm{~cm}^{-1}$ at the expense of free hydroxyl band due to hydrogen bonding through carbonyl carbon (silane) and phosphoryl phosphorus (titanate). The value of occupied area of an organotitanate on the surface of red mud (table 2) is in agreement with other reported data on particulate fillers e.g. mica (Favis et al 1983) and clay (Ishida 1983). However, good interface between organotitanate treated red mud and resin matrix and high occupied surface area of organotitanates on the surface of red mud due to hydrogen 


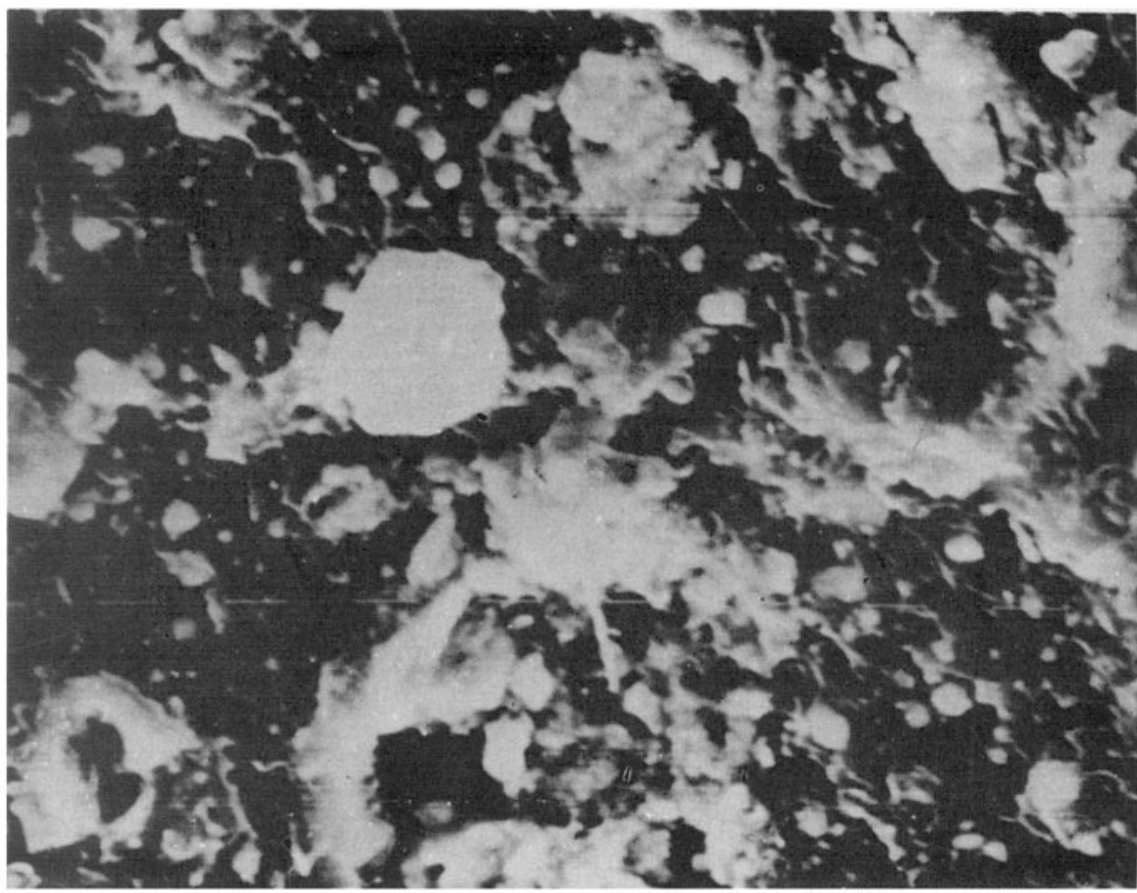

Figure 6. SEM of fracture surfaces of red mud-filled polyester resin showing presence of largest red mud particulate $(\times 768)$.

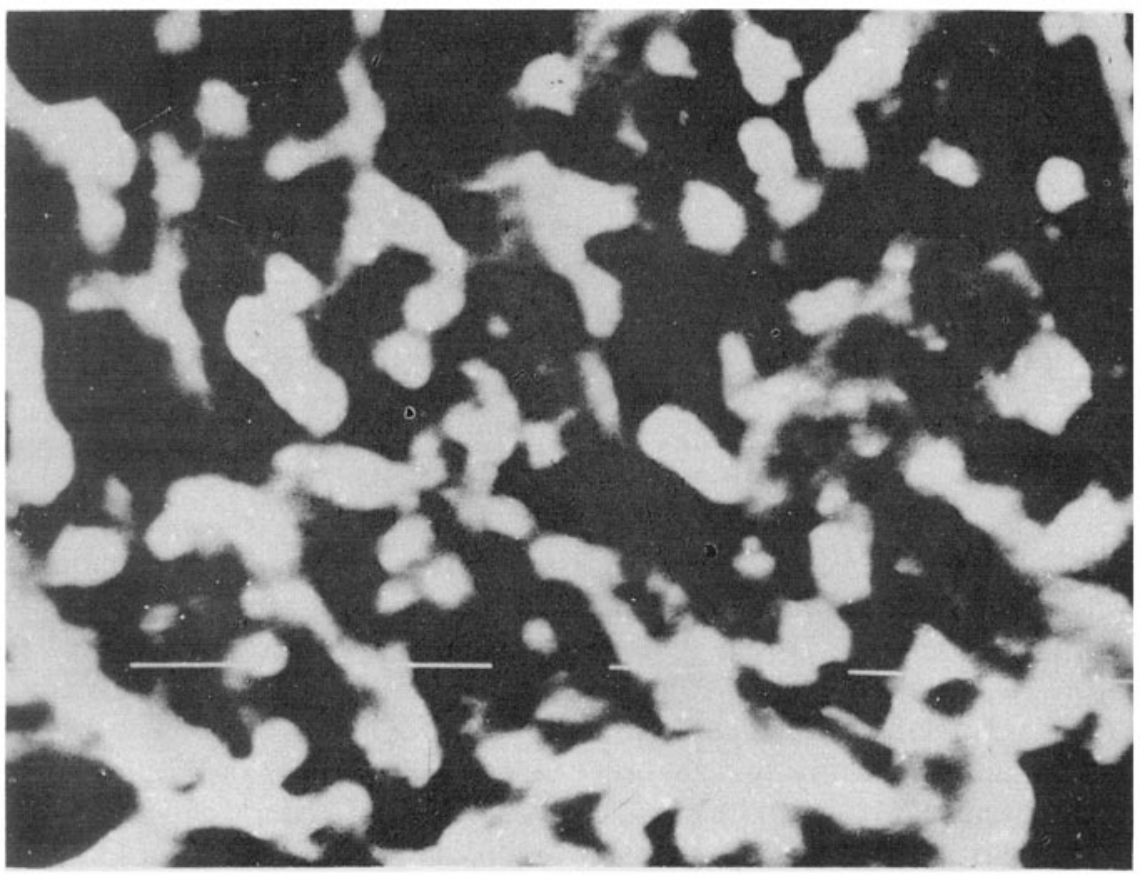

Figure 7. SEM of fracture surfaces of red mud-filled polyester resin showing particle deformation $(\times 1500)$. 


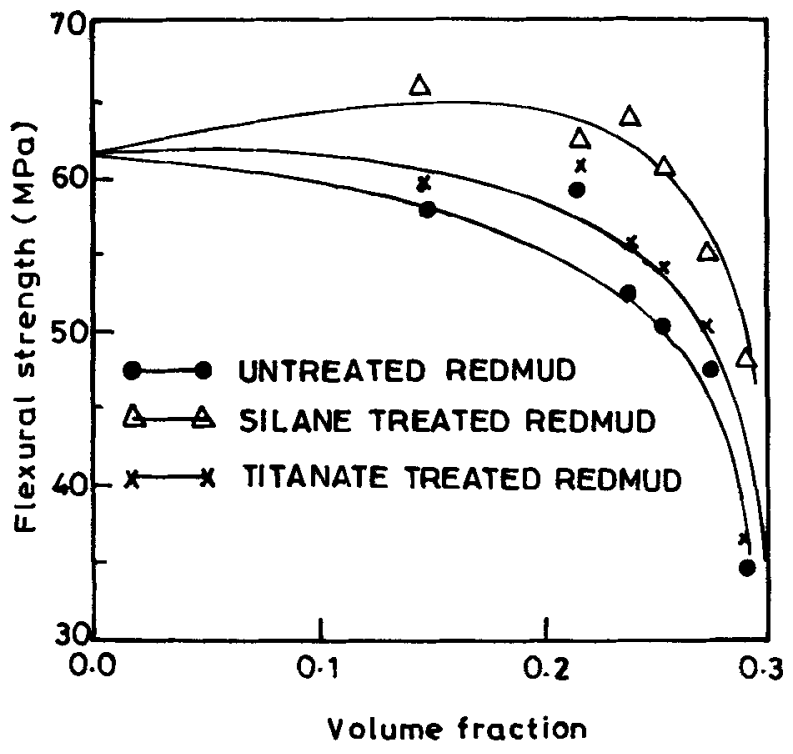

Figure 8. Variation of flexural strength vs red mud loadings for particulate filled-composites (coupling agents $=1 \%$ by wt. of red mud).

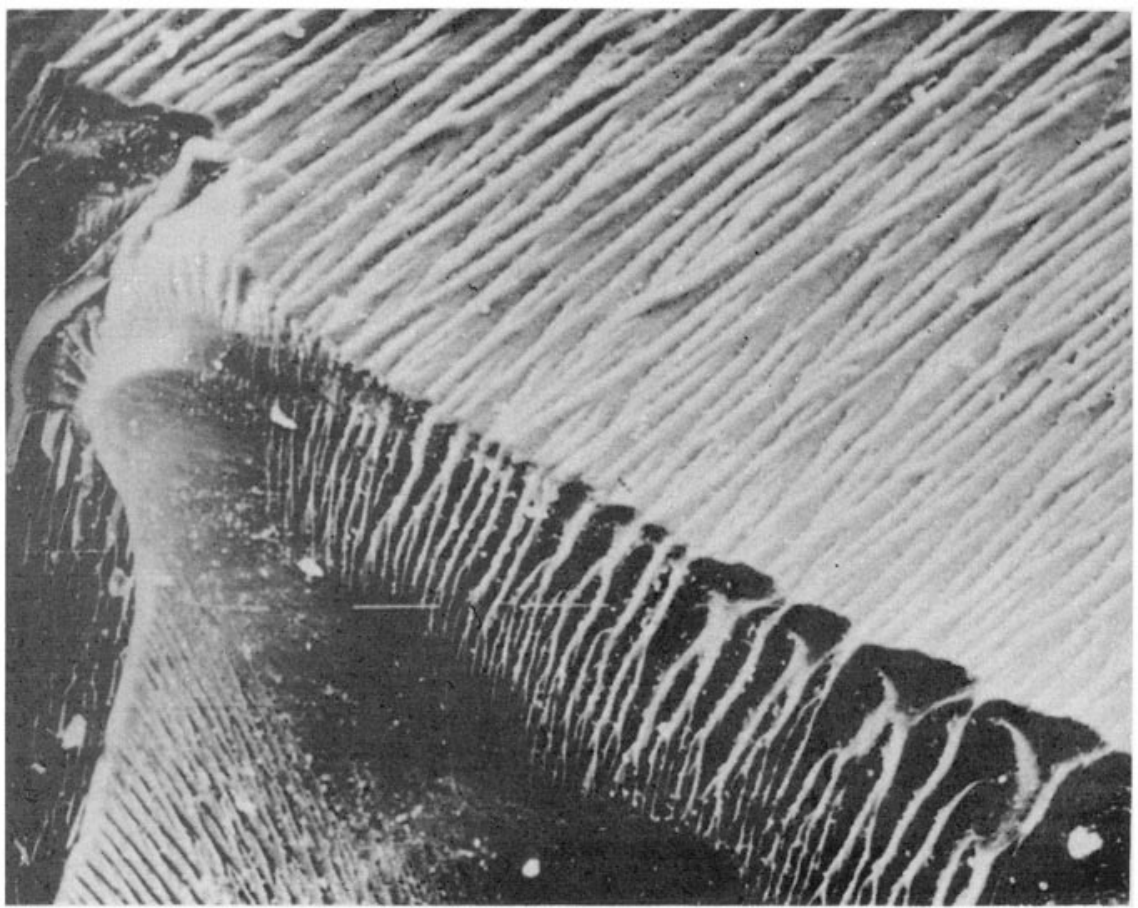

Figure 9. SEM of fracture surface of neat resin showing a typical arrest line along with striations ( $\times 104)$ (flexure mode). 

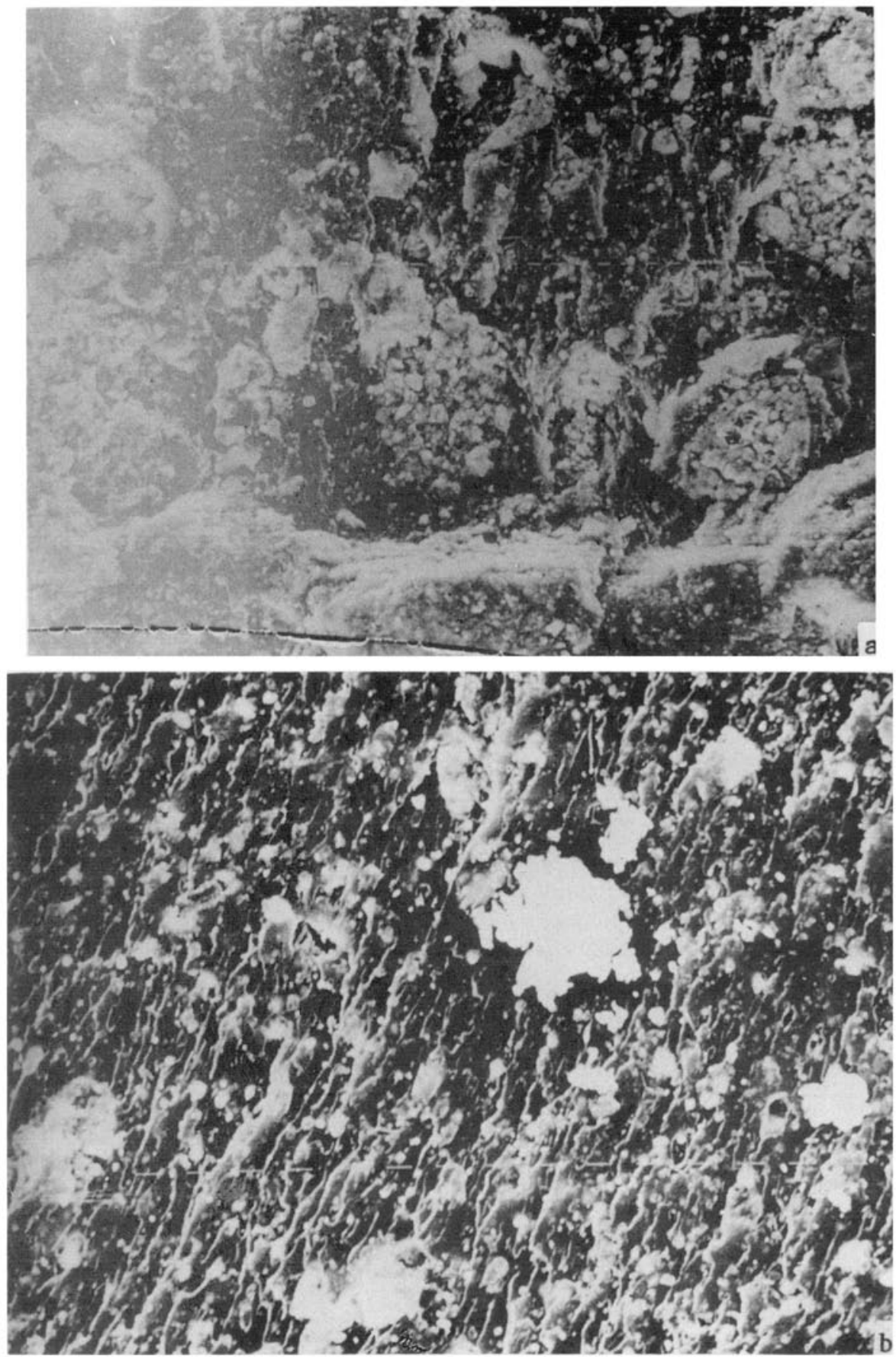

Figure 10. a. SEM of fracture surfaces of red mud-filled polyester composites showing particles agglomeration $(\times 208$ ) (flexure mode) and b. showing characteristic fracture steps and slipping of particles from the agglomerates $(\times 352)$ (flexure mode). 


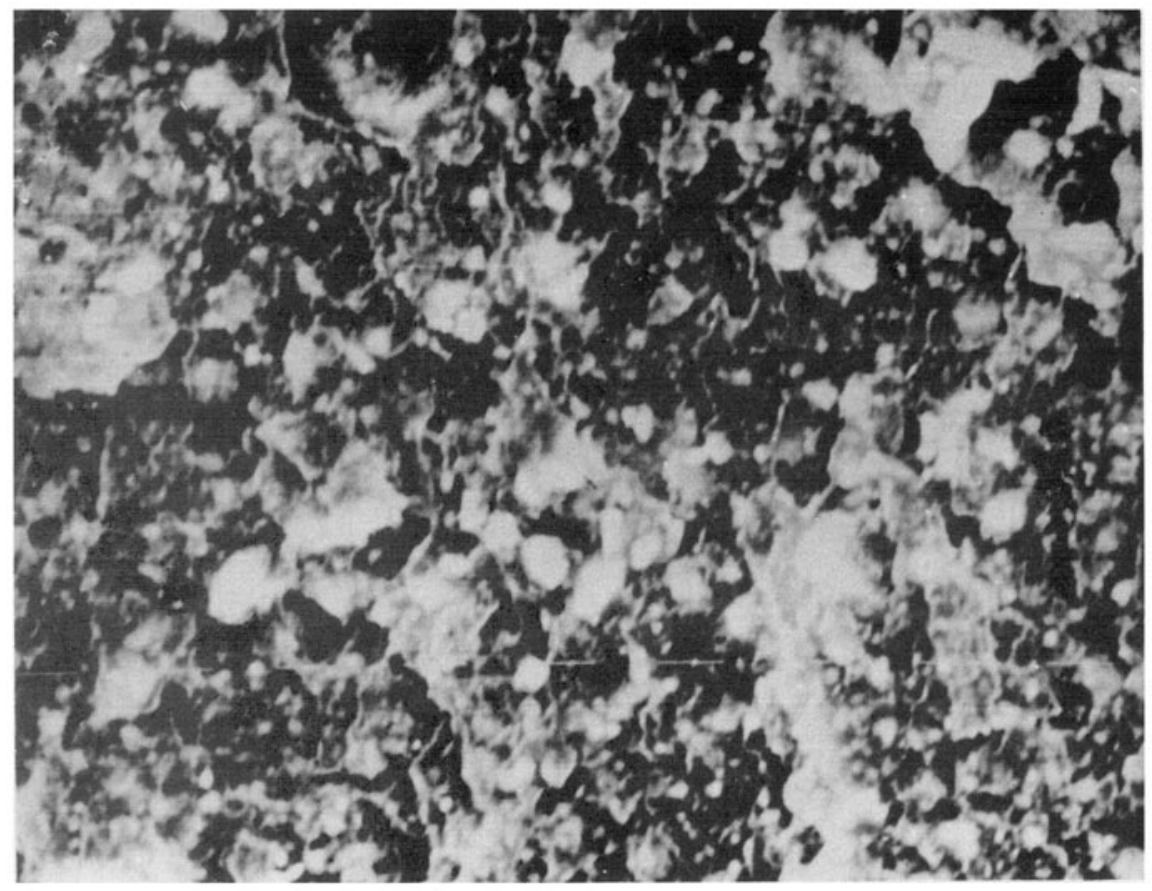

Figure 11. SEM of fracture surface of organosilane treated red mud-filled polyester composites showing debonding and matrix cracking $(\times 768)$ (flexure mode).

bonded carbonyl/phosphoryl groups to the surface are responsible for better physicomechanical properties of these composites.

The flexural strength of both untreated and treated red mud-filled polyester composites was studied before and after exposure to $24 \mathrm{~h}$ in boiling water (table 3 ). It was observed that organosilane treated red mud-filled polyester composites retained higher flexural strength of its original strength $(72 \%)$ than the composites prepared from organotitanate treated red mud $(68 \%)$, organozirconate treated red mud $(69 \%)$ and EZEBOND titanate treated red mud $(67 \%)$. It is assumed that organofunctional group bonded to a central atom through oxygen $(\mathrm{Zr}-\mathrm{O}-\mathrm{R}-\mathrm{Y}$ or $\mathrm{Ti}-\mathrm{O}-\mathrm{R}-\mathrm{Y})$ have poorer hydrolytic stability than the organofunctional group attached directly to central atom through stable $\mathrm{C}-\mathrm{Si}$ bond and therefore do not provide a water resistant bond between an organic matrix and an inorganic filler/reinforcement.

As seen in figure 5, there is continuous increase in absorbed water content up to 10 days immersion in water and then levels off. For polyester with treated red mud, the water absorption is about $50-70 \%$ of the matrix (except organozirconate treated red mud $-96 \%$ ) and for untreated red mud, it is about $118 \%$ of the matrix absorption. At $60^{\circ} \mathrm{C}$, the water absorption of treated red mud-filled polyester resin is roughly two to three times better than the untreated ones (table 3 ). This suggests that with the treated red mud, the strong interfacial bond prevents the polymer swelling away from the red mud surface while in the untreated case, the action of moisture results in the partial disruption of the bonds between red mud and resin and the subsequent formation of additional cavities which would be filled with water. Similar effects have been described in the literature for glass-filled methacrylate resins (Soderholm and Calvert 1983). 
Table 5. Effect of coupling agents ( $1 \%$ by wt. of red mud) on the properties of different percentages of red mud-loading in unsaturated polyester resin.

\begin{tabular}{|c|c|c|c|c|c|c|c|}
\hline \multirow{2}{*}{$\begin{array}{l}\text { Red mud } \\
\text { loading } \\
\text { ( } \% \text { by volume) }\end{array}$} & \multirow{2}{*}{$\begin{array}{c}\text { Coupling agents } \\
\text { used }\end{array}$} & \multirow{2}{*}{$\begin{array}{l}\text { Density } \\
\left(\mathrm{g} / \mathrm{cm}^{3}\right)\end{array}$} & \multicolumn{2}{|c|}{$\begin{array}{c}\text { Water absorption } \\
(24 \mathrm{~h}, \%)\end{array}$} & \multirow{2}{*}{$\begin{array}{c}\text { Flexural } \\
\text { strength } \\
\text { (MPa) }\end{array}$} & \multirow{2}{*}{$\begin{array}{c}\text { Tensile } \\
\text { strength } \\
(\mathrm{MPa})\end{array}$} & \multirow{2}{*}{$\begin{array}{l}\text { Elongation } \\
(\%)\end{array}$} \\
\hline & & & RT & $60^{\circ} \mathrm{C}$ & & & \\
\hline Unfilled & - & $1 \cdot 18$ & $0 \cdot 130$ & 0.169 & $61 \cdot 26$ & $26 \cdot 43$ & $2 \cdot 85$ \\
\hline 15 & $\begin{array}{c}\text { - } \\
\text { organotitanate } \\
\text { organosilane }\end{array}$ & $\begin{array}{l}1 \cdot 36 \\
1 \cdot 32 \\
1 \cdot 31\end{array}$ & $\begin{array}{l}0 \cdot 163 \\
0 \cdot 101 \\
0 \cdot 121\end{array}$ & $\begin{array}{l}- \\
0.202 \\
0.221\end{array}$ & $\begin{array}{l}58 \cdot 00 \\
66 \cdot 29 \\
60 \cdot 00\end{array}$ & $\begin{array}{l}21 \cdot 00 \\
23 \cdot 35 \\
22 \cdot 56\end{array}$ & $\begin{array}{l}2 \cdot 75 \\
2 \cdot 63 \\
2 \cdot 61\end{array}$ \\
\hline 22 & $\begin{array}{c}- \\
\text { organotitanate } \\
\text { organosilane }\end{array}$ & $\begin{array}{l}1 \cdot 40 \\
1 \cdot 44 \\
1 \cdot 40\end{array}$ & $\begin{array}{l}0.255 \\
0.126 \\
0.162\end{array}$ & $\begin{array}{l}0.560 \\
0.244 \\
0.187\end{array}$ & $\begin{array}{l}59 \cdot 16 \\
62 \cdot 49 \\
61 \cdot 02\end{array}$ & $\begin{array}{l}20 \cdot 15 \\
22 \cdot 46 \\
21 \cdot 00\end{array}$ & $\begin{array}{l}2 \cdot 56 \\
2 \cdot 50 \\
2 \cdot 45\end{array}$ \\
\hline 25 & $\begin{array}{l}- \\
\text { organotitanate } \\
\text { organosilane }\end{array}$ & $\begin{array}{l}1.57 \\
1.56 \\
1.52\end{array}$ & $\begin{array}{l}0.432 \\
0.191 \\
0.184\end{array}$ & $\begin{array}{l}0.772 \\
0.297 \\
0.168\end{array}$ & $\begin{array}{l}50 \cdot 09 \\
60 \cdot 62 \\
54 \cdot 69\end{array}$ & $\begin{array}{l}15 \cdot 91 \\
19 \cdot 25 \\
17 \cdot 75\end{array}$ & $\begin{array}{l}2 \cdot 40 \\
2 \cdot 30 \\
2 \cdot 33\end{array}$ \\
\hline 27 & $\begin{array}{l}\text { organotitanate } \\
\text { organosilane }\end{array}$ & $\begin{array}{l}1.64 \\
1.65 \\
1.55\end{array}$ & $\begin{array}{l}0.438 \\
0.236 \\
0.225\end{array}$ & $\begin{array}{l}0.821 \\
0.320 \\
0.253\end{array}$ & $\begin{array}{l}47 \cdot 40 \\
55 \cdot 00 \\
50 \cdot 42\end{array}$ & $\begin{array}{l}14 \cdot 37 \\
18 \cdot 48 \\
16 \cdot 80\end{array}$ & $\begin{array}{l}2 \cdot 38 \\
2 \cdot 22 \\
2 \cdot 15\end{array}$ \\
\hline 29 & $\begin{array}{l}- \\
\text { organotitanate } \\
\text { organosilane }\end{array}$ & $\begin{array}{l}1.72 \\
1.73 \\
1.64\end{array}$ & $\begin{array}{l}0.470 \\
0.322 \\
0.230\end{array}$ & $\begin{array}{l}0.818 \\
0.496 \\
0.313\end{array}$ & $\begin{array}{l}34.99 \\
47 \cdot 85 \\
36 \cdot 78\end{array}$ & $\begin{array}{c}11 \cdot 77 \\
15 \cdot 89 \\
14.90\end{array}$ & $\begin{array}{l}1.90 \\
1.70 \\
1.73\end{array}$ \\
\hline
\end{tabular}

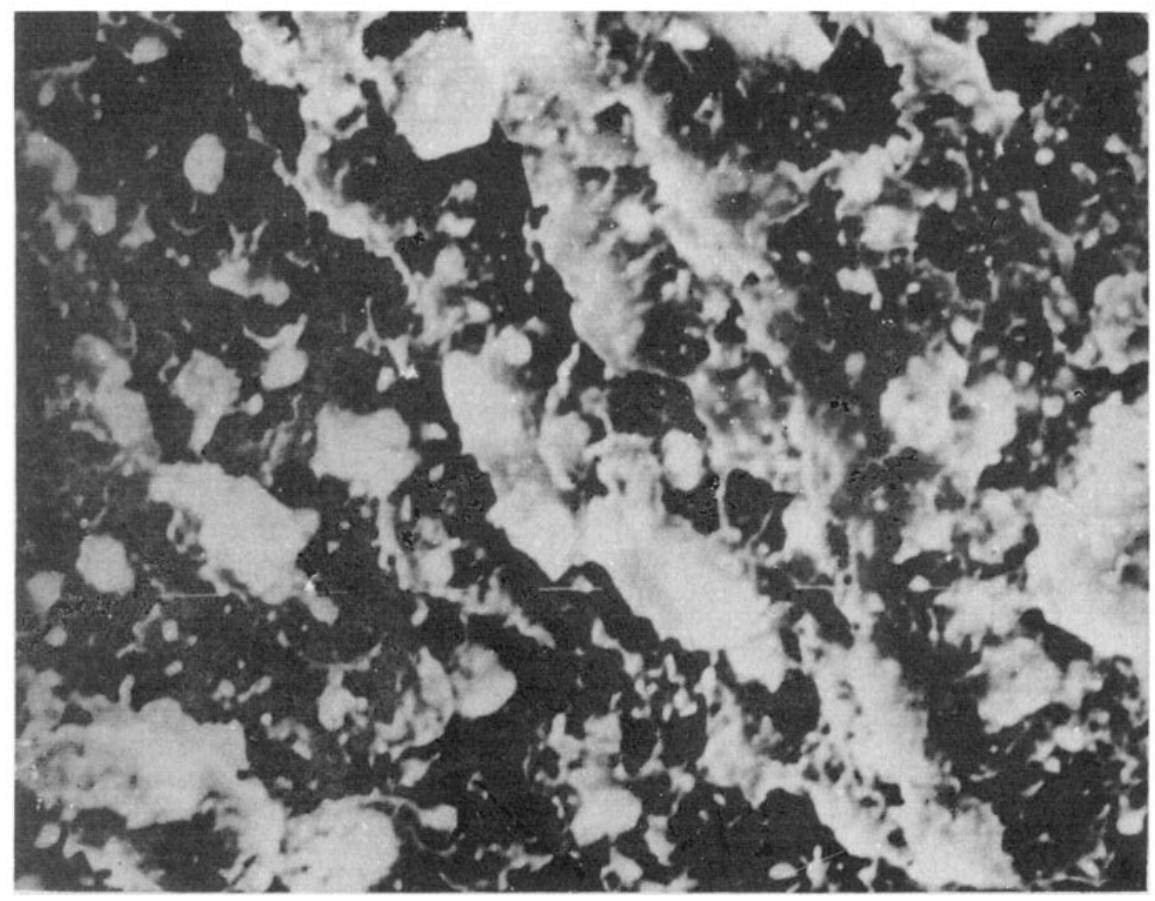

Figure 12. SEM of fracture surface of organotitanate treated red mud-filled polyester composites showing geod bonding between the particles and the matrix $(\times 768)$ (flexure mode). 


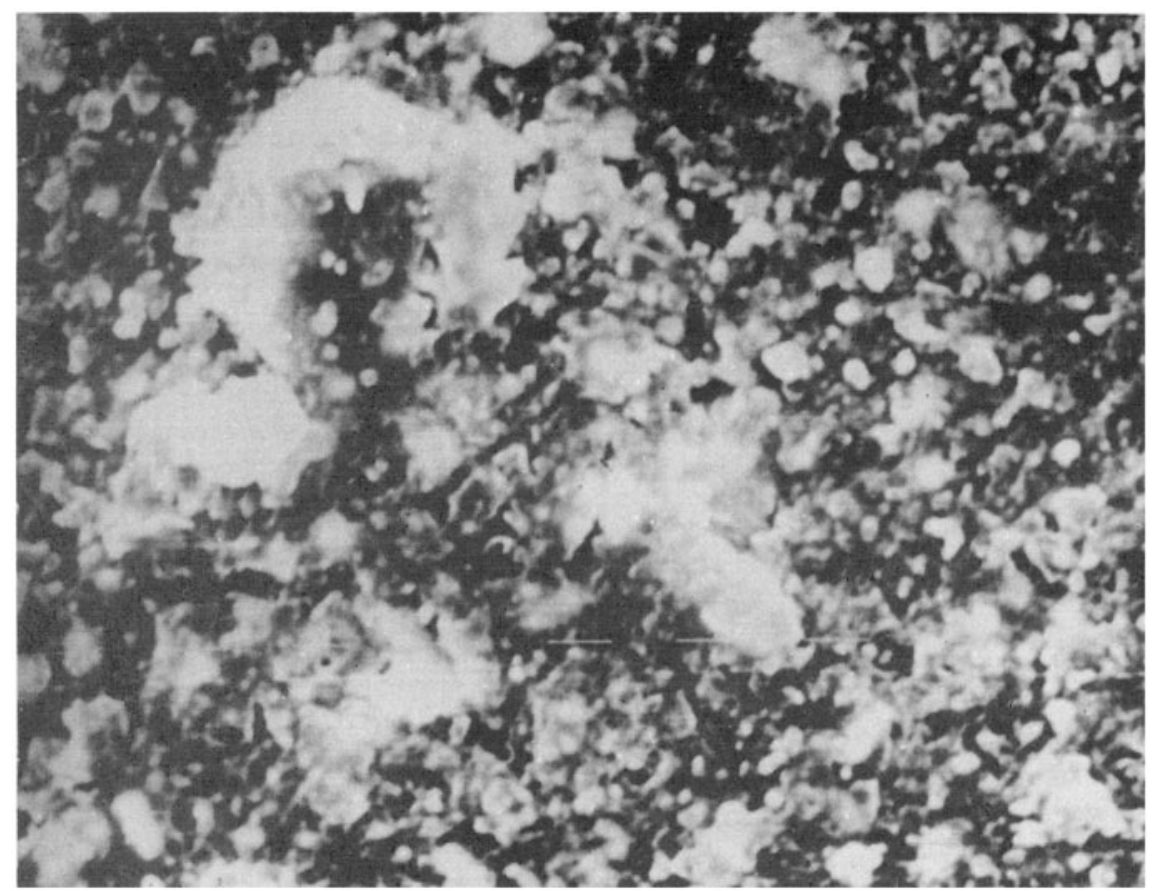

Figure 13. SEM of fracture surface of organozirconate treated red mud-filled polyester composite showing localized particles dispersion along with some milky regions $(\times 704)$ (flexure mode).

Table 4 shows the effect of average particle size and its distribution on the tensile and flexural strength of particulate composites. At constant volume fraction, increasing particle size of red mud decreases the strength of resulting composites as reported similarly for other fillers such as silica (Moloney et al 1987), alumina (Pritchard and Wainwright 1993) etc. The extent of reduction could be assessed by the presence of largest red mud particle (figure 6) or agglomeration to act as critical flaws as seen in figure 10b. SEM of fracture surfaces (figure 7) showed trans-particle deformation failure rather than debonding, even with untreated red mud. The weak particles of red mud are easily deformed under stress and their effects are rather different from those of stronger fillers. It was also observed that irregular rough particles (untreated) have a higher tendency to agglomerate than smooth particles. Ahmed and Jones (1990) suggested that if the volume fraction of filler is high, inter-particle contact will always occur and the particle distribution will be rathe: insensitive to agglomerations.

Table 5 shows the effect of coupling agents on the properties of red mud-filled polyester composites with different red mud loadings. The reduction in strength properties with different percentages of red mud loading has already been reported in our earlier publication (Singh et al 1995). With surface treated red mud-filled polyester composites, an improvement in physico-mechanical properties was observed as reported similarly for many soft fillers such as alumina trihydrate (Redford 1971), dolomite (Moloney et al 1983), hollow glass bead (Moloney et al 1984). The desired improvement could not be achieved because red mud does not respond well to these coupling agents, although it may have some surface hydroxyl groups. It is assumed 
that the molecular weight of adsorbed oligomers onto red mud seem to be small and desorbed easily during processing (Ishida 1983). At lower red mud loading (up to $20 \%$ by volume) the flexural strength of surface treated red mud-filled polyester resin is comparable to the strength of unfilled resin and a subsequent decrease with further addition (figure 8). This is attributed mainly due to inherent weakness of filler particles, since the particles themselves act as sources of flaws. Organotitanate treated red mud-filled polyester resin showed the highest value of both tensile and flexural strength properties because of its better pyro-phosphato organofunctionality interaction with resin and alkoxy group with available surface active proton of red mud.

SEM of fracture surfaces of unfilled and filled resins are shown in ìgures 9-13. In an unfilled resin (figure 9), a typical arrest line along with closely spaced striations parallel to the direction of crack growth and a smooth relatively featureless mirror region (plastic flow) in the extreme right on figure was observed. Similar striations have also been reported in epoxy resins (Young 1980) and phenol-formaldehyde resins (Nelson and Turner 1972). In red mud-filled polyester composites, failure may initiate in the matrix, as before or at resin/filler interfaces or within agglomerates of the particles. Evidence for this conclusion can be seen in figure 10, where the characteristic fracture steps were associated with each particle and each step intersected the neighbouring particles. The nucleation of voids due to decohesion of particles from the resin-matrix interface and slipping of particles from the weakest portion of the agglomerate was clearly visible on the fractured surface (figure 10b). For organosilane treated red mud-filled polyester composites, the failure accumulates in the form of resin-particle debonding and matrix cracking (figure 11) while organotitanate treated red mud-filled polyester composites show a smooth region where the particles are well bonded to the matrix (figure 12), indicating efficient stress transfer between the particles and the matrix. A pronounced localized milky zone of lower density (stress whitening) alongwith poorly dispersed particles was observed on the fractured surface of organozirconate treated red mud-filled polyester composites (figure 13). Under applied stress, these debonded/slipped particles would act as stress concentrators and will propagate rupture through the bulk specimen resulting in low strength of particulate-filled polyester composites.

\section{Conclusions}

Our observations show that the usage of organotitanate coupling agent for the surface treatment of red mud provides a substantial benefit in the processing and physicomechanical properties of red mud-filled polyester composites. It would also help in minimizing the debonding between the particles and the matrix at the interface and also agglomeration of red mud particles in the resin matrix. Further work is in progress to formulate red mud-filled polyester paste and mortars.

\section{Acknowledgements}

The authors thank Anchal Verma for providing necessary assistance in several experimental measurements. They also thank Dhan Prakash Yadav for useful help. 


\section{References}

Ahmed S and Jones F R 1990 Composites 2181

Aramine F, Horst W and George B 1961 Chem. Abstr. $5519296 \mathrm{~d}$

Broutman L J and Sahu S 1971 Mater. Sci. Eng. 898

Chand N 1991 Proc. national symp. on substitute for wood in buildings, Roorkee, p. 49

Daniel F K 1950 Nat. Paint Varnish \& Lacquer Assn. Sci. Sec. Circular 744 \& 745

Eckstein Y and Berger E J 1983 Proc. Org. Coat. Appl. Polym. Sci. 4823

Favis B D, Blanchard L P, Leonard J and Prod'homme R E 1983 J. Appl. Polym. Sci. 281235

Guruviah S and Rajagopalan K S 1966 Paint India 1631

Han C D, Sanford C and Yoo H J 1978 Polym. Eng. Sci. 18849

Ishida H 1983 in Molecular characterization of composite interfaces (eds) H Ishida and G Kumar (New York: Plenum Press) pp 25-50

Ishida H and Koenig J L 1978 Polym. Eng. Sci. 18128

Ishida H and Koenig J L 1980 J. Polym. Sci. Phys. 181931

Katz H S and Milewski J V 1978 Handbook of fillers and reinforcements for plastics (Toronto: Reinhold)

Kenyon A S 1968 J. Colloid. Interf. Sci. 27761

Kenyon A S and Duffy H J 1970 Polym. Sci. Eng. 71

Ketomo A G 1952 Chem. Abstr. 46 10674d

Moloney A C, Kausch H H and Stieger H R 1983 J. Mater. Sci. 18208

Moloney A C, Kausch H H and Stieger H R 1984 J. Mater. Sci. 191125

Moloney A C, Kausch H H, Kaiser T and Beer H R 1987 J. Mater. Sci. 22381

Molphy M, Laslett R L, Gunatillake A P, Rizzardo E and Mainwaring D E 1994 Polym. Int. 34425

Monte S J and Sugerman G 1981 SPI RP/C Instit 18-D

Nelson B E and Turner D T 1972 J. Polym. Sci. 102461

Panda L K 1992 Proc. national seminar on utilization of red mud (Bhubaneswar: RRL) p. 15

Plueddemann E P 1982 Silane coupling agents (New York: Plenum Press)

Plueddemann E P 1983 in Molecular characterization of composite interfaces (eds) H Ishida and G Kumar (New York: Plenum Press) pp 13-23

Pritchard G and Wainwright R 1993 in Advanced composites, 93 (eds) T Chandra and A K Dhingra (Warrendale, PA: TMS) pp 629-635

Ramanujam S and Saluja R V 1965 Chem. Abstr. 63 797c

Redford K C 1971 J. Mater. Sci. 61286

Rodriguez E L and Newaz G M 1988 Polym. Comp. 993

Singh B, Gupta M and Verma A 1995 Const. \& Build. Mater. 939

Soderholm K J and Calvert P D 1983 J. Mater. Sci. 182957

Spandoukis J and Young R J 1984 J. Mater. Sci. 18288

Sung N H, Kaul A, Chin I and Sung C S P 1982 Polym. Eng. Sci. 22637

Union Industrial Research Laboratory (UIRL), Taiwan Republic of China, Personal Communication

Vogel F 1965 Chem. Abstr. $6312724 \mathrm{e}$

Wong R $1972 J$. Adhesion 4171

Young R J 1980 in Developments in reinforced polymers (ed.) G Pritchard (London: Applied Science) 